\title{
THE SUNDANESE PUPPETS APPERANCE AS THE REPRESENTATION OF THEIR CHARACTERS IN MAHABHARATA PLAY
}

\author{
Ida Lisdawati \\ ida_lisdawati9088@gmail.com \\ STKIP Siliwangi Banding
}

\begin{abstract}
This study not only aims to introduce Sundanese culture which is part of Indonesian culture, but also analyses the phenomenon that exists in Sundanese puppets performance as one of the entertainment for the Sundanese people with Semiotic. In this study, the researcher analyzed two factors that determined the result of this research. Firstly, the researcher found the role of color as a kind of pictorial metaphor. In each puppet, it will be seen whether the dominant color of puppet represents the characteristics corresponding to the color or has a significant difference. The secondly, the researcher analysed the appearance of each puppets. This research used four puppets from category of Panakawan, two puppets from category of Knight, and two puppets from category of Giant. Qualitative method is used for describing the result and the result showed that almost puppets appearance represented their character except Cepot that also known as Astrajingga. His appearance did not represent his characteristic especially his color face.
\end{abstract}

Keyword Semiotics, Sundanese puppets, color of Sundanese puppet.

\section{A. INTRODUCTION}

Sundanese, one of the tribe populating the province of West Java, is one of the largest provinces in Indonesia. It is associated with religion and belief because it is received many influences from Hindu and Islamic culture proved by the history of Tarumanagara kingdom that stood around the 5th century AD. The area adhere Hindu culture are Rangkasbitung, Bogor, Puwakarta, Subang, Sumedang and Indramayu, while the influence of Islam on the Sundanese comes from the area of Cirebon where the data collected indicates a commercial relationship brought by Islamic merchants who come from Parsi, Pasai, Malaka, Arabic and India. The other data indicate that Cirebon is the center of Islamic deployment is based on Purwaka Caruban Nagari story that tells the history of Islamic dissemination brought by Susuhunan Jati in 1470 became religion teacher and appointed become head of local area to lead it (Ekajati, 1980:90).

In West Java, there is one area that is not affected by the two religions and cultures derived from these two religions namely Banten region holds a belief called the Sunda Wiwitan. It emphasizes good deeds and not hurting others (Ekadjati, 1980:25). In Sunda wiwitan belief, a functionary has three assistants who have different tasks. Firstly is Tangkesa as an astrologer. Secondly is Jaro Dangkat as the supervisor of the territory of Dangka and the last is Gurang Seurat as a leader of religious ceremony. Because of their belief, Baduy 
residents limit the influence that goes into the baduy tribal ares so that makes the Baduy tribe who live in south Banten is the only region in the West Java awakened its customs.

A famous Sundanese artist, Ajip Rosidi, states that Sundanese art has a variety of vocal music called "tembang" where it is a culture that comes from the mixing of Javanese and Sundanese culture. Tembang itself eventually developed into "papantunan" and "dedegungan" and the other art getting influence from Hindu is puppet (Ekadjati, 1980:147). The use of Mahabarata and Ramayana stories is evidence that Indonesian culture is influenced by Hindu culture brought by Indian traders although the puppet itself originated from Javanese culture that eventually developed into a part of Sundanese culture. In essence, the difference between Mahabharata and Ramayana lies in the time difference of the story Mahabharata tells the story of the royal period of Barata, while Ramayana tells the king of Rama (Salamu in Suryana, 2002).

The first type of puppet in Java is "Wayang Kulit Purwa" developed into "Wayang Golek Purwa" in West Java. Wayang golek (Suryana, 2002: 12) is a communication tool used by puppeteers to convey the values of kindness to the audience so that not only become a form of entertainment but also become a tool of learning about religious and social values (Suryana, 2002:20).

In manufacture of "wayang golek", the creator must allow the rules called 'Pakem'. It is the rule that must be followed in the making of the puppets where the manufacture must go through the stages that have been determined. The coloring of a puppet becomes a necessity in addition to making the puppets more interesting and staining. It is also required to distinguish between the characters of each puppet. In certain puppets, the selection of color on the face is able to explain its character. According to the philosophy of color, each color represents certain traits such as red can represent a character that has high emotion / temperamental and black can symbolize someone who has firm attitude.

\section{LITERATURE REVIEW}

\section{Semiotics}

The term semiotics comes from the Greek 'semeion' meaning 'sign' or 'seme' which means the interpretation of the sign (Cobley and Jansz in kaelan, 2009: 162). Theories about semiotics can use the opinions of Peirce and Saussure. According to Saussure, semiotics is part of the study of the role of the sign that is part of life based on structularisation and develops in general linguistic principles, while Peirce states that the understanding of semiotics emphasizes the logical understanding that explains how reasoning people do by studying the signs of more emphasis on logic, pragmatics and linguistics so that it can be explained semiotics is a sub-study of language philosophy that emphasizes the study of signs (Kaelan, 2009:160)

Sign in semiotics is not only in the literal sense but encompassing a wider range of things. It is a device used to find a way to understand life. Sign not only explains an object, but also belongs to a literary work, a movie, and even a bird song can be categorized into a sign in human life. How it can explain depends on how the reader can connect between the sign and the signified (Zoest, 1992: vii, Kaelan, 2009: 162).

In grouping the sign, Peirce divides into 10 kinds of signs, such as dictated indexical leg sign. The understanding contained in this group indicates that the sign can explain the subject's information, such as the use of traffic signs to indicate that the road has a contour 
that is quite dangerous (Pateda, 2001: 44, Kaelan, 2009: 196)

\section{Sundanese Wayang Golek}

"Wayang Kulit" and "Wayang Golek" are the famous puppets in Indonesia that have a quite prominent difference. "Wayang kulit" is a culture that originated from East Java and Central Java so that it is known as 'Javanese group', which means that puppet is the result of Javanese culture without any element of culture influencing it. This statement is supported by the number of studies (Suryana, 2002: 48) which shows that puppet is a legacy of Javanese culture where puppet has relation with social, cultural, and religious life Javanesse (Suryana, 2002: 59).

The beginning 1900's, puppet show held with taking the story of Mahabharata. This opinion was conveyed by the 'Indian group' who had the opinion that there are two cultures that influence each other in the development of puppet, namely Javanese and Hindu culture. It is evident that puppet is found at the region of Java and Bali where it is most influenced by Hindu culture and the discovery of the separator between women and men when they are watching the puppet performances are estimated to be a relic of Hindu culture in carrying out the initiation ceremony brought by the Hindu aide who came to Java.

The type of puppet can be categorized based on the story, the way of staging and the material of manufacture. The type of puppet based on wayang golek story itself comes from Cirebon, the border area between West Java and East Java which is named 'wayang golek papak' or 'wayang golek cepak'.

The development of "wayang golek" in Cirebon is related to the development of Islam used as a medium for spreading of Islam by Sunan Gunung Jati who at that time took control of the government in the 15th century. It is developed in the 19th century with the opening of a highway by Daendels that penetrates the isolated areas in West Java so puppets can flourish.

Change of Javanese language to Sundanese language is done by Wiranatakoesoemah IV' government because many Sundanesse who are good at playing puppet show. In the early use of Sundanese in puppet performance, he assigned a puppeteer from Tegal area called Ki Anting. This puppet is a combination of ideas from Dalem Karang Anyar, regent of Bandung regency in 1840's, and Ki Darman, the maker of wayang kulit, and perfected by Wiranata Koesemah III.

In manufacture of puppet, it is tied to the grips that must be followed by the puppet maker such as head position, facial color, eyebrow pattern, eye pattern, nose pattern, nutmeg, and mouth pattern which represent the character and characteristic of certain puppet (Suryana, 2002: 12).

The puppet lineament divided into three: the first is the character roles. In the golek puppet, the role is divided into four groups namely the knights, ponggawa, giant, and panakawan. The second is the appearance of figures such as Arjuna, Gatotkaca, Semar, and the last is the Wanda's character that specifically describes the physical, or certain popular character environments.

The gentle and honest night puppets displayed with bow head, white face, narrow eyes, and sharp nose. Ponggawa characters portrayed as the handsome puppet, gallant, large eyebrows, and sharp nose. Giant puppets are depicted with the red face, large eyebrows, 
goggle eyes, big nose, thick moustache, big mouth and canine, while the expression of panakawan is illustrated with funny face.

\section{Color of Sundanese Puppet}

The study of color of puppet is begun by with R.L.Mellema who states that the color on the puppet's face is a sign of his character, such as the puppet that are characterized as having bad character, greed, arrogance, quick temper and others has red face. There are four basic colors used in the puppets namely red, white, gilts, and black. Besides using basic color, the puppet can use combined color such as red and white for producing pink so that the puppet will have combined character between red and white characters (Suryana, 2001:110)

In addition for describing the puppet character, the color can also describe a particular state or meaning such as red. It associated with the tempered, pompous and something that is not good character, but if red is related to the state of something or of a certain meaning, then red may symbolize brave, white portrays humility although in reality the color meaning may not be the same from one place to another.

The color grouping known in the Sundanese tradition is known as 'nu opat kalima pancer' in which the insight refers to the four points of the compass that symbolize nature and work. The north wind is denoted by a black that has a rigid nature, in which the work corresponding to that is a helper. Southern winds, symbolized in red, which has a greedy nature becoming the nature of the trader who seeks to profit as much as possible for its own sake. The western wind has a yellow symbol representing the nature of showing off. The puppet has a look up head posture symbolize the arrogant nature. The eastern wind currency is symbolized by a white that has sufficient properties like a farmer trying to provide the needs of the people by planting rice, while the center of these winds has multicolor representing the articulate nature that is usually the nature of a king who only reigns for his desires (Suryana, 2001:116).

\section{RESEARCH METODHOLOGY}

\section{The Method}

This study uses Descriptive-analysis. This method is part of qualitative research used to explain the puppet character based on their color face and appearance. Descriptive research is used for describing the result based on data. It will represent, analyze, and interpret of data.

\section{The method and technique of Data Collection}

The writer collects Golek puppet based on their group. The researcher chooses four puppets from category of Panakawan, two puppets from category of Knight, and one puppet from category of Giant.

\section{The Method and Technique of Data Analysis}

After deciding the puppets that will be analyzed, the researcher tries to determine the puppet character based on their color face and appearance. The procedure of data analysis consists of three steps. The first step is the researcher analyses of color and physically identitity from the puppets. The second one is the researcher tries to determine of meaning from the puppets' color and appearance, and the last step is the writer makes a conclusion based on the result.

\section{FINDING AND DISCUSSION}


Based on the sample that researcher took for this research, sample consisted of four puppets from category of Panakawan, two puppets from category of Knight, and one puppets from category of Giant. The result would presented in descriptive paragraph:

\section{Semar is a member of Panakawan}

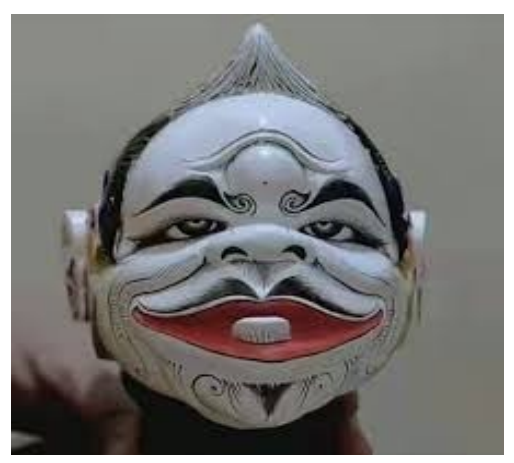

Picture 1 Semar

Semar was a leader of Panawakan group of Sundanese puppet; he had characteristic features such as upturned and white face, "gendul" nose, and "cameh meseum" mouth. Semar had white face because he represented sufficient attitude. It described a quiet, unselfish, and always giving change to others attitudes. His face position was upturned because he was described as a character who always giving advises that we as human should follow God's rules. He had "cameh mesem" mouth. "cameh" was a under lip position which exceeded up lip, meanwhile "mesem" meant smile in sundanese. This mouth portrayed a corky and humorist character. The last characteristic feature of Semar was his nouse that included to "gendul shape". In Sundanese, this nose described as a big nose. Based on this explanation, Semar could be described as a good character. He always tried to be good role model for his circumstance.

2. Astrajingga/Cepot is a member of Panakawan

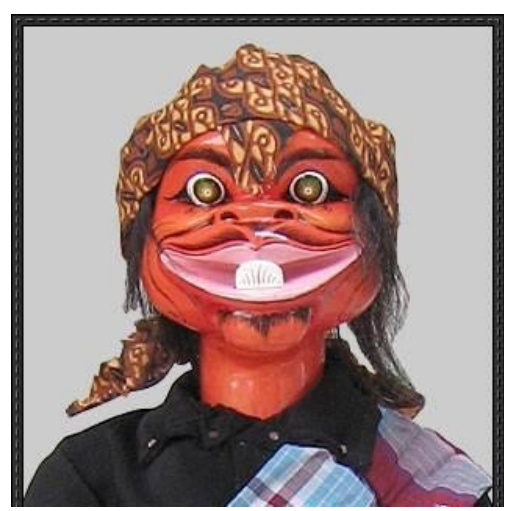

Picture 2 Astrajingga/Cepot

Cepot was a member of Panawakan group of Sundanese puppets; he had characteristic features such as upturned and red face, "gendul" nose, and "cameh meseum" mouth. Red was identified as a bad character such as selfish, sly, and always using much ways to get everything that he wanted, but in this case, Cepot was described as puppet which had characteristic features as selfish, sly, flirtatious, but he also had a good character as brave and loyal. His color only showing Cepot's identity. His face position was upturned because he 
was described as a character who always giving advises. He had "cameh mesem" mouth. "cameh" was a under lip position which exceeded up lip, meanwhile "mesem" meant smile in sundanese. This mouth portrayed a corky and humorist character. The last characteristic feature of Cepot was his nose included to "gendul shape". In Sundanese, this nose described as a big nose. Based on this explanation, Cepot could be described as a good character; even sometime he could be someone who nettled others.

3. Dawala is a member of Panakawan

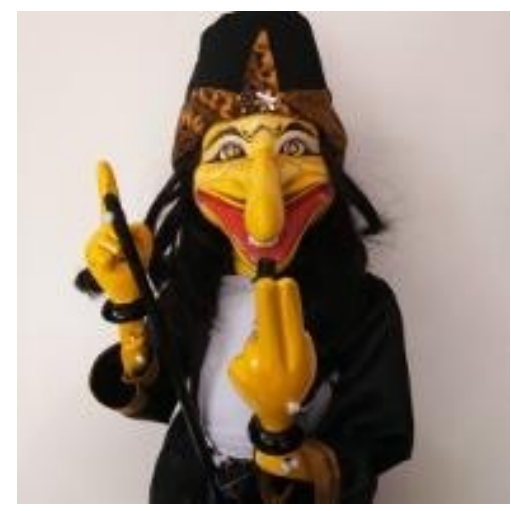

Picture 3 Dawala

Dawala was a member of Panawakan group of Sundanese puppets; he had characteristic features such as upturned and pink face, long nose, and "cameh meseum" mouth. If we associated his face with color of psychology, it represented characters such as resignation, demanding, cute and humorist. He had "cameh mesem" mouth. "cameh" is a under lip position which exceed up lip, meanwhile "mesem" means smile in Sundanese. This mouth portrayed a corky and humorist character. The last characteristic feature of Dawala was long nose which was not given any meaning. Based on this explanation, Dawala could be described as a humorist character.

4. Gareng is a member of Panakawan

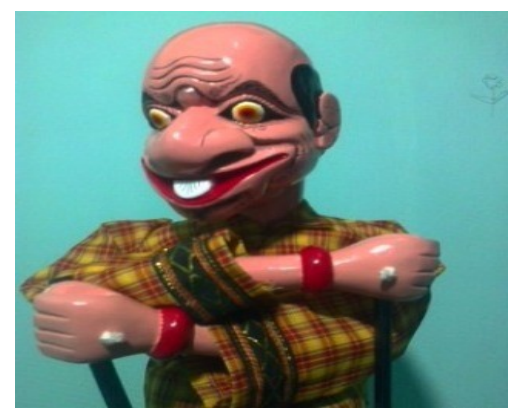

Picture 4 Gareng

Gareng was a member of Panawakan group of Sundanese puppets; he had characteristic features such as ivory face, "bunder" nose, and "gusen"mouth. The color of Garnet's face represented calm, warm. The negative of this color was less responsibility and unstable. Judging from the nature, the figure of Gareng in wayang golek included of silent characters, statements made by him sometimes inconsistent, but still had a sense of such as Cepot and Dawala. had "jujung" eye type represented nimble and rough character. He also had "gusen" mouth shape. Gusen was the shape of the mouth that showed gums, teeth or fangs. This 
mouth shape represented the character of evil and wicked, and 'bunde"nose because he had a big nose. Based on the above explanation, Dawala was a puppet showed character who was described as a rough, inconsistent and reserved figure, but he also has good character that he had the same sense of humor as dawala and Cepot.

5. Bima is a member of Knight

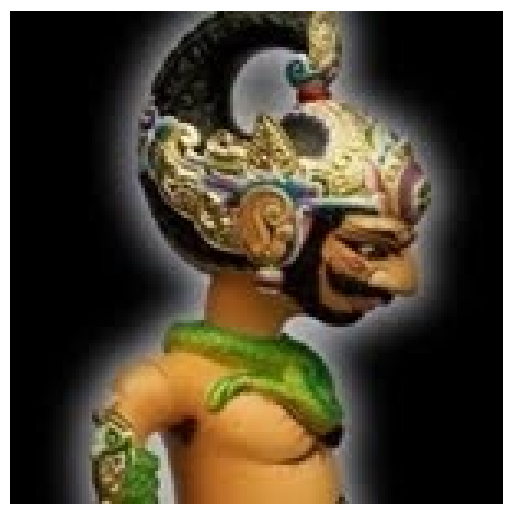

Picture 5 Bima

Bima had the characteristics such as bow head, ivory face, "gabahan" eye, small nose and "salitan" mouth. The ivory or beige possessed by Bima if associated with the color chromatic symbolized the gentle nature such as calm and warm. Judging from the nature, the figure of Bima as a silent character, statements made sometimes inconsistent. He was known as an honest person, but he was not easily instigated or influenced by anything, even though the agitator used various moves and ways. Bima also had a very deep tolerance for anyone, so he would immediately provide help to anyone who was hit by misfortune and distress. He was also very strong in keeping with religious and state law. He was a patriotic figure who was always faithful to the environment. This eye represented a sharp and careful eye. Based on the statement above, it could be concluded that Bima was categorized as a good figure, and he has knight spirit.

6. Arjuna is a member of Knight

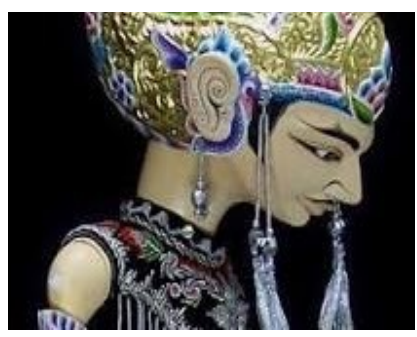

Picture 6 Arjuna

Arjuna had haracteristic features such as "tungkul" head position, white face, "gabahan eyes", small nose and "salitan" mouth. The white of Arjuna possessed a sufficient stance. It described a calm character, unselfish and always giving opportunity to others. Arjuna eyes included to "gabahan" shape. It meant that Bima had narrow eyes. It represented sharp and careful eyes. He also had "salitan mouth". It was the form of mouth that was widely used in the puppet group that has good character. Based on the explained above, it could be concluded that the character Arjuna had the admirable nature. Arjuna was not only the symbol of subtlety and greatness of a man's mind, but also very sensitive soul, and gentle 
heart.

7. Duryudhan is a member of Knight

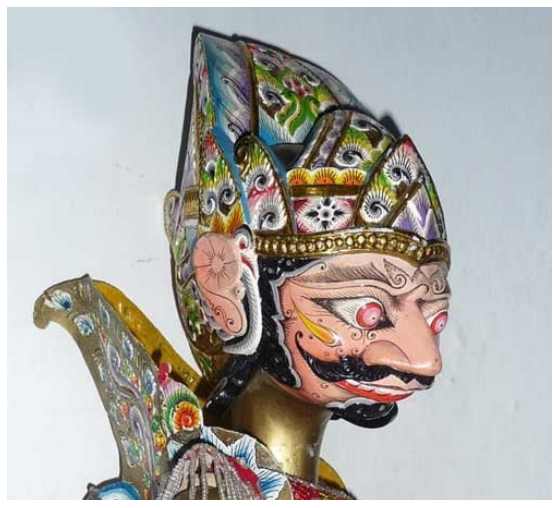

Picture 7 Duryudhan

Duryudana had characteristics such as bow head, ivory face, "peten" eyes, and the "salitan" mouth. The ivory or beige possessed by Duryudana if associated with the color chromatic symbolized the gentle nature such as calm and warm. Judging from these traits, the figure of Duryudana in wayang golek included to honest character, easily affected by his ignorant. He also had "peten" eyes and "salitan" mouth that is the form of mouth that was used in the puppet group that has good character. Based on the characteristic, Bima was categorized as a good figure, and has knight spirit.

7. Dursasana is a member of Giant.

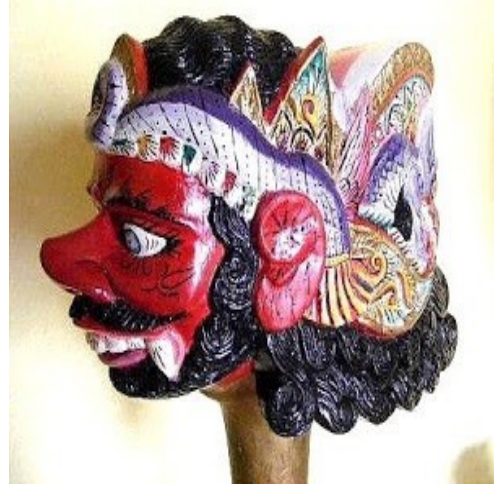

Picture 7 Dursasana

Dursasana had characteristic features such as upturned head, red face, "rembesan” eye, sharp nose and "gusen" mouth. Red had positive and negative views. Positive outlook: love, energy, power, power, suffering, negative heat: anger, danger, warning, impatience. The red possessed by the Dursana represented a pompous nature. He always insulted everyone. He also had "plankengan" describing the ruthless. Dursasana also had "gusen" mouth. Based one explanation above, it can be concluded that the Duersasana was an antagonist character that has a lot of vices , such as the evil character, arrogant, reckless, like talking loud, cocky, arrogant, likes to laugh, insult each other, and so on.

\section{CONCLUSION}


Based on the result above, the writer concludes that the color cannot represent their characters. As we know that red is represented as a bad thing such as bad character, but it does not mean that puppet which has black face has bad character. Astrajingga is a puppet which has red face, but in fact he is still has good attitude. He is known as funny and loyal character. In the other hand, Dursana also has red face and he has most negative attitude as representation of red character. He is antagonist, arrogant, and reckless puppet.

\section{BIBLIOGRAPHY}

Ekadjati, E S. (1980). Masyarakat Sunda Dan Kebudayaanya. PT Girimukti Pusaka, Jakarta.

Kaelan. (2009). Filsafat bahasa Semiotic dan Hermeneutik. Paradigm, Jogjakarta.

Narbuko and Abu Achmadi. (2012). Methodology Penelitian. Bumi Aksara, Jakarta

Riduwan. (2012). Belajar Mudah Penelitian untuk Guru-karyawan dan Peneliti Pemula. Penerbit Alfabeta, Bandung.

Suryana, J. (2002). Wayang Golek Sunda:kajian Estetika Rupa Tokoh Golek . PT. Kiblat Utama.Bandung. 